\title{
T-Cell Receptor Alpha Chain
}

National Cancer Institute

\section{Source}

National Cancer Institute. T-Cell Receptor Alpha Chain. NCI Thesaurus. Code C26426.

One component of the alpha-beta T-cell receptor. Encoded by a locus on chromosome 14. Somatic recombination results in formation of the active gene. 